\title{
SOEP
}

SOEPpapers

SOEPpapers
on Multidisciplinary Panel Data Research
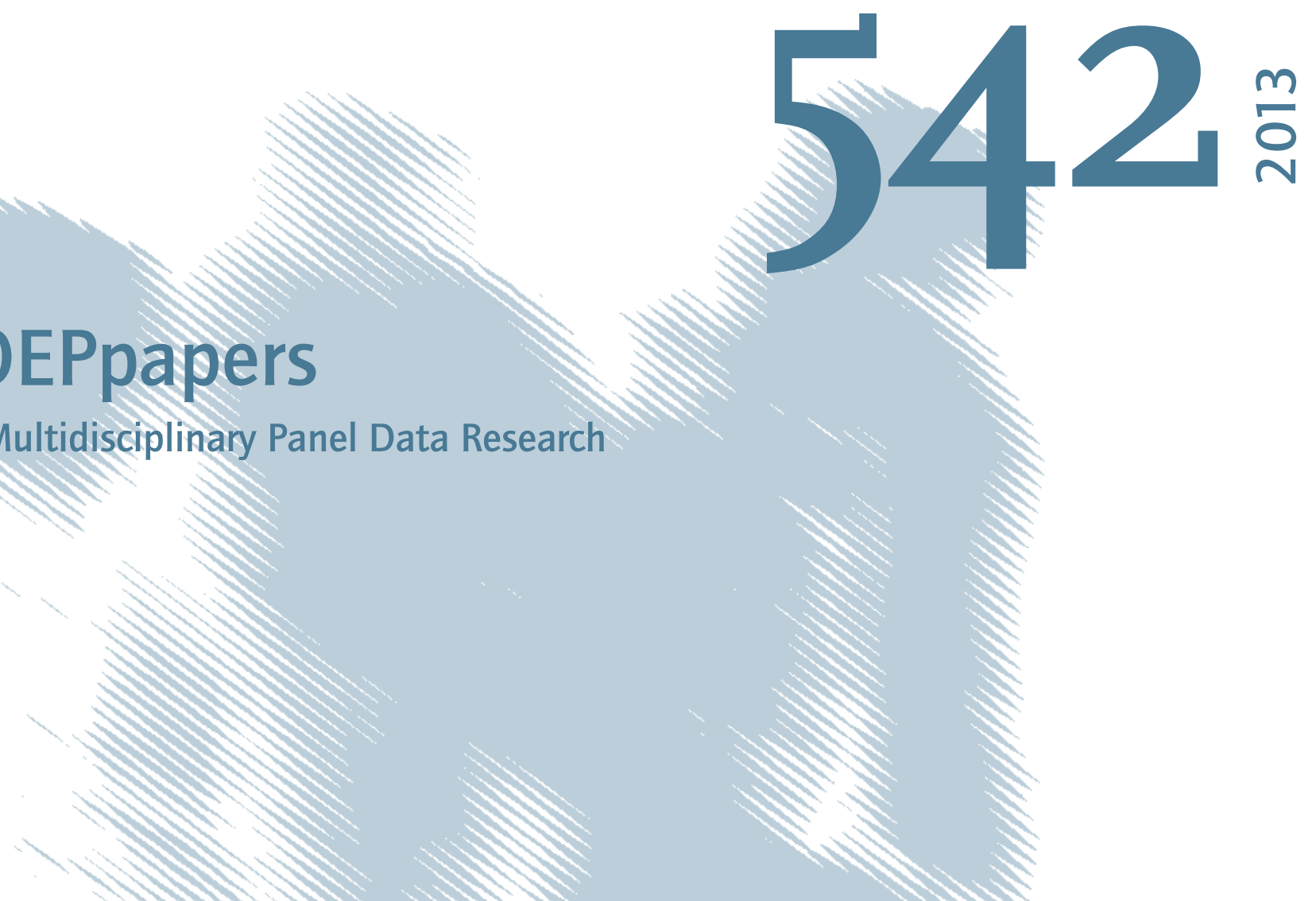

han $\quad x_{n}$

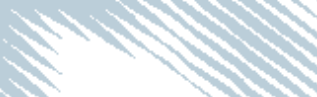

$\mathbb{2}$

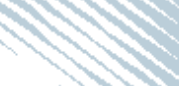

\section{Impacts of Parental Health Shocks on Children's Non-Cognitive Skills}

Franz Westermaier, Brant Morefield, Andrea M. Mühlenweg 


\section{SOEPpapers on Multidisciplinary Panel Data Research}

at DIW Berlin

This series presents research findings based either directly on data from the German SocioEconomic Panel Study (SOEP) or using SOEP data as part of an internationally comparable data set (e.g. CNEF, ECHP, LIS, LWS, CHER/PACO). SOEP is a truly multidisciplinary household panel study covering a wide range of social and behavioral sciences: economics, sociology, psychology, survey methodology, econometrics and applied statistics, educational science, political science, public health, behavioral genetics, demography, geography, and sport science.

The decision to publish a submission in SOEPpapers is made by a board of editors chosen by the DIW Berlin to represent the wide range of disciplines covered by SOEP. There is no external referee process and papers are either accepted or rejected without revision. Papers appear in this series as works in progress and may also appear elsewhere. They often represent preliminary studies and are circulated to encourage discussion. Citation of such a paper should account for its provisional character. A revised version may be requested from the author directly.

Any opinions expressed in this series are those of the author(s) and not those of DIW Berlin. Research disseminated by DIW Berlin may include views on public policy issues, but the institute itself takes no institutional policy positions.

The SOEPpapers are available at

http://www.diw.de/soeppapers

\section{Editors:}

Jürgen Schupp (Sociology, Vice Dean DIW Graduate Center)

Gert G. Wagner (Social Sciences)

Conchita D'Ambrosio (Public Economics)

Denis Gerstorf (Psychology, DIW Research Director)

Elke Holst (Gender Studies, DIW Research Director)

Frauke Kreuter (Survey Methodology, DIW Research Professor)

Martin Kroh (Political Science and Survey Methodology)

Frieder R. Lang (Psychology, DIW Research Professor)

Henning Lohmann (Sociology, DIW Research Professor)

Jörg-Peter Schräpler (Survey Methodology, DIW Research Professor)

Thomas Siedler (Empirical Economics)

C. Katharina Spieß (Empirical Economics and Educational Science)

ISSN: 1864-6689 (online)

German Socio-Economic Panel Study (SOEP)

DIW Berlin

Mohrenstrasse 58

10117 Berlin, Germany

Contact: Uta Rahmann | soeppapers@diw.de 


\title{
Impacts of Parental Health Shocks on Children's Non- Cognitive Skills
}

\author{
Franz Westermaier*, Brant Morefield\#, Andrea M. Mühlenweg士 \\ * Philipps-University Marburg \\ \# Abt Associates Inc., Durham NC \\ \pm Leibniz University Hannover and Centre for European Economic Research (ZEW), \\ Mannheim
}

Version: 02.02.2013

\begin{abstract}
We examine how parental health shocks affect children's non-cognitive skills. Based on a German mother-and-child data base, we draw on significant changes in selfreported parental health as an exogenous source of health variation to identify effects on outcomes for children at ages of three and six years. At the age of six, we observe that maternal health shocks in the previous three years have significant negative effects on children's behavioral outcomes. The most serious of these maternal health shocks decrease the observed non-cognitive skills up to half a standard deviation. Paternal health does not robustly affect non-cognitive outcomes.
\end{abstract}

JEL Classification: I00, J24, I10

Keywords: Human capital, health, non-cognitive skills

\section{Corresponding author:}

Franz Westermaier

Philipps-University Marburg

Chair of Public Economics

Am Plan 2

D-35032 Marburg

westermaier@uni-marburg.de

Acknowledgements: We thank Dave Ribar for very valuable comments on an earlier version of this paper. Additionally, helpful comments were received from Verena Niepel, Frauke Peter, Patrick Puhani, C. Katharina Spieß, Christian Traxler and Joachim Winter. The paper has further benefited from fruitful discussions with our colleagues and conference participants at the International Institute of Public Finance congress in Dresden, the Royal Economic Society conference in Cambridge, the Leibniz network conference in London and the ZEW workshop on Health and Human Capital in Mannheim. Financial support by the Leibniz Association within the project "Non-Cognitive Skills: Acquisition and Economic Consequences" is gratefully acknowledged. 


\section{Introduction}

Parental investments are crucial for the children's skill development, especially in the early years of the life-cycle. Differences in skill investments lead to early and persistent differences in achievement or skill measures across children (Carneiro and Heckman 2003; Crouse et. al. 1998; Fryer and Levitt 2004; Todd and Wolpin 2007). Skills are built over time. Hence, without sufficient remediation, a drop in skill investment in a period will lessen the skill levels in future periods. Remediation in the form of increased investments in future periods is often difficult and inefficient in skill production, because investments across periods of development are complements rather than substitutes. Therefore, a reduction in one period of investment may not be remediated by an equal increase in investment in the following period (Heckman 2000). This paper examines how parental health shocks, which may cause variation in investments in children's skill formation, affect children's levels of specific noncognitive skills. Based on German data, we observe how significant negative changes to parental health (shocks) occurring when the children are six years or younger affect children's socio-emotional skills measured when the children are six years old.

It is often assumed that children's skills are formed via parental investments of time and resources early in children's life (cf. the technology of skill formation, Cunha et al. 2006). When a parent suffers from a negative health change, poor health alters constraints and, therefore, optimal behaviors of the parent. For example, poor parental health may depress the quality of parent-child relationships and poor health can reduce the productivity of parental time (Ruhm 2004) or the amount of parental time (Morefield 2010). In turn, these changes negatively affect the level of resources invested in children. Additionally, a less healthy adult may face tighter budget constraints, ceteris paribus, because she spends down family wealth due to health (Wu 2003), is less productive in the labor market and receives a lower wage or is limited by the hours worked (Currie and Madrian 1999). Poor parental health is therefore suggested to tighten a family's monetary budget constraint and to reduce investment in (the normal good) child development. ${ }^{1}$

Consistent with these arguments, we find that maternal health shocks in early childhood significantly affect children's emotional symptoms, hyperactivity and conduct problems by the age of six. Paternal health is not robust in explaining the levels of these noncognitive characteristics. Our identification assumption is tested using the timing of parental health shocks to form a falsification test. In this manner, we demonstrate that our model finds significant effects for maternal health shocks occurring before, but not after, the child

\footnotetext{
${ }^{1}$ Further literature on income changes due to health shocks includes Adda et al. (2009), Riphahn (1999) and Smith (2004).
} 
outcomes are measured. Further specification checks show that our results are robust after controlling for annual income or events such as parental split-off or divorce and maternal and paternal job-losses. While an examination of the mechanisms that link parental health and child outcomes is beyond the scope of this paper, our analysis suggests that the effects are driven by reduced quality or quantity of parental time rather than lower financial investments in children's non-cognitive skills.

This paper stands in the tradition of recent empirical studies demonstrating the importance of early life events on human capital development. While the general importance of home investments in early life has been shown (e.g. Todd and Wolpin 2007; Blomeyer et al. 2009) $)^{2}$, attempts to quantify the effects of commonly experienced household shocks are more limited. ${ }^{3}$ For Germany, Berger et al. (2010) present evidence on changes in family structure with a focus on children's non-cognitive development and show that permanent maternal unemployment is related to lower adaptive behavior scores for children. Similarly, Berger and Spieß (2011) find that maternal life satisfaction positively affects children's verbal and socio-emotional skills. ${ }^{4}$

In addition to previous studies we consider a battery of non-cognitive outcomes and observe these outcomes at early years of childhood together with the parental health shock history, from birth to the age of six. There are several other papers that seek to identify causal effects of parental health on child outcomes, however, they focus on different outcome variables: ${ }^{5}$ Andrews and Logan (2010) examine whether parental health status accounts for test-score gaps between ethnicities of school-age children. The authors find that controlling for a large set of parental health measures reduces the gap between black and whites (Hispanic and whites) by 17 percent (10 percent). Sun and Yao (2010) draw on a long panel of rural Chinese households to analyze how parental health shocks impact school-aged children's educational attainment. The paper documents that parental health shocks especially

\footnotetext{
${ }^{2}$ A further stream of the literature looks at the effects of breastfeeding on children's skill development (e.g. Belfield and Kelly 2012 or Rees and Sabia 2009).

${ }^{3}$ An exception is the literature studying the effects of changes in family structure on children's outcomes (cf. Ribar 2004 for a review with a focus on marriage).

${ }^{4}$ One further stream of the related literature studies parental death, which might be considered as the most extreme health shock (cf. Adda et al. 2011 for a recent paper and a review of evidence. They find small negative effects on skill development and somewhat lower earnings later in life for affected children.)

${ }^{5}$ Our work also relates to studies that examine the impact of maternal psychiatric illness, smoking during pregnancy, commonly depression or substance abuse, on children's outcomes. The results consistently show that children of depressed mothers fare worse than children of mothers who do not suffer depression on a wide range of outcomes including development of cognitive and motor skills (Albers and Petterson 2001), number of problem behaviors (Frank and Meara, 2009), and increased anti-social behavior (Caspi et al. 2005). Castilla et al. (2011) investigate the impact of smoking during pregnancy on early child neurodevelopment. Their results imply adverse effects on children's neurodevelopment with larger effects for the low-SES sample. Farahati et al. (2003) find that parental psychiatric illness is associated with a significantly lower probability of high school graduation.
} 
harm elementary school children, while the effects are not significantly different from zero for children in secondary school. They identify limited financial resources due to increased health expenditures as the main driving force of reducing primary school participation.

Most closely related to our work is Morefield (2010), who examines the relationship between parental health limitations and child outcomes in the US. He studies how the onset of a parental health event, defined as the onset of one of several specific health conditions or a work limiting disability, affects children's achievement test scores and problem behavior. According to this paper, parental health events during late childhood (ages 5 to 9) significantly increase children's problem behavior. Additionally, Morefield shows that when parental health events are estimated to most negatively affect behavior outcomes, large reductions in one measure of skill investment (i.e. time that parents participate in activities with children), are also commonly found.

We distinguish from these contributions not only because of different outcome measures and different times of observation, but also in using data from a different country. We expect that maternal health shocks are especially severe in Germany, a country where early childcare institutions are relatively rare and mothers are the primary care-givers of their children.

The remainder of our paper proceeds as follows: Section 2 introduces the data and descriptive evidence. The empirical approach is discussed in Section 3. Section 4 presents the results together with robustness checks. Section 5 concludes.

\section{Data and Descriptive Evidence}

Our empirical analysis is based on the German Socio-Economic Panel Study (SOEP). The SOEP is a representative annual panel study of private households in Germany, which has been conducted since 1984, with 2011 being the most recently available wave. The annual samples record information from over 20,000 adults from approximately 12,000 households including health-related information, from which we are able to identify levels and changes in health. The most consistently fielded health-related question, available in all years of the survey, gathers self-reported satisfaction with the respondents' health-from zero, completely dissatisfied, to ten, completely satisfied. Another available, and perhaps more objective, 
measure of health is the number of nights the respondent spent in the hospital during the previous year. $^{6}$

We define health shocks as major changes in the respondent's level of health satisfaction and the number of nights to be hospitalized during the year between survey rounds. By using significant changes in the health variables rather than movement below a "poor" health threshold, we are able to reduce the potential bias from correlation between the level of health and unobserved individual characteristics. This shock-based approach has been previously employed in the literature. Hagan et al. (2009) using the European Community Household Panel (ECHP) and define the threshold change for a shock by observed variation in the variable. Specifically, the authors define a health shock as a change in the health measure of interest from period $t$ to period $t+1$ greater than one standard deviation of the health measure. Although the number of standard deviations required to move for a health shock is subjectively defined, this measure incorporates information on the observed variance of the data to define a health shock. We follow Hagan et al. (2009) and Riphahn (1999) to define health shocks in terms of year-on-year standard deviation changes of the respective measures to capture these with a health shock.

In our data, one standard deviation of the health satisfaction distribution corresponds to two points on the eleven point (zero to ten) scale for mothers and fathers. ${ }^{7}$ For nights spent in the hospital, one standard deviation is equal to six nights for mothers and to four nights for fathers. We define a shock in health satisfaction as a year-on-year decrease in health satisfaction of two or more standard deviations (four points) ${ }^{8}$ and a shock in hospitalizations as a year-on-year increase of one standard deviation in the number of nights. Based on these two measures, we create four alternative shock definitions: (1) a shock in health satisfaction

\footnotetext{
${ }^{6}$ Additional SOEP health questions include whether the respondent had a new health limitation, new handicap, new chronic disease, health deterioration, days of sick-leave, sick-leave greater than 6 weeks continuously, current state of health, number of hospital visits, any medical care after a work accident, and any doctor visit in the previous 3 months. However, this information was only collected biannually over our period of interest, is conditional on employment or covers only a short period before the interview in each year. As such, these measures are not appropriate for our estimation strategy, which relies on the timing of changes in health measures.

${ }^{7}$ The definition of a shock necessitates that a parent start the observation period with a health satisfaction rating that allows a drop of four points, necessarily correlating health with our shock measure. However, only five percent of parents report health satisfaction scores below the minimum threshold for a shock (satisfaction $\leq 3$ ). In results not shown, removing the low health satisfaction respondents from our sample does not alter the results. ${ }^{8}$ Our definition of maternal health shocks will usually not identify hospitalizations for child-birth as a maternal health shock. According to Schneider (2008), German child-bearing mothers spend on average 2.8 days in hospital.
} 
or nights of hospitalization; (2) a shock in health satisfaction; (3) a shock in nights of hospitalization; and (4) a shock in both health satisfaction and nights of hospitalization. ${ }^{9}$

In 2003, the SOEP began collecting additional "mother and child data," information on new-born children (i.e. younger than 1.5 years) and their mothers in SOEP households. After the first survey of newborns in 2003, the mother-child questioning was repeated when the children were about three years old (2-3 years) and again when they were about six years old (5-6 years). ${ }^{10}$ The available sample of children from the newborn sample, observed at age six, is 703, born between 2002 and 2005. Our analysis excludes observations with missing information for mother's age at birth (23 obs.), week of childbirth (15 obs.) and the birth weight of the child ( 2 obs.), reducing the sample to 663 observations of children with their parents. Out of these we observe the SDQ (VAB) outcome, as discussed below, for 639 (634) children.

Not all children have a father in the home. However, we treat a male adult person living in the household as the father. According to this definition, 21 percent of the children in the sample do not have a father in the household.

As a measure of non-cognitive skills at age six, we draw on a modified version of the Strength and Difficulties Questionnaire (SDQ) (Goodman 1997). The SDQ is based on the mothers' assessments of the child's behavior and socio-emotional skills. We show results for two different measures which are derived from the SDQ, children's socio-emotional behavior (SEB) and the pro-social behavior score (PBS). ${ }^{11}$ The SEB is based on the following four dimensions: emotional symptoms, conduct problems, hyperactivity/inattention, and peer relationship problems (in the sense of the child's popularity among peers). The rating of PBS is based on the mothers' reports on the children's thoughtfulness, sharing and helpfulness. We will report results separately for each of these sub-scores.

Children's skills at the age of three years are measured according to the Vineland Adaptive Behavior Scale, which is based on parental information concerning children's verbal skills, activities of daily living, motor skills, and social skills. ${ }^{12}$ However, the focus of our study is on the non-cognitive measures we observe for the six-year-olds. The Vineland score

\footnotetext{
${ }^{9}$ We observe that roughly $30 \%$ of mothers who experience a negative change of more than 2 standard deviations in health satisfaction experienced a corresponding shock defined by the number of nights spent in hospital early in children's life.

${ }^{10} 70 \%$ of children in our sample are two (five) years old, when they were assessed in the VAB (SDQ), the other $30 \%$ are one year older. One reason why we do not focus on adaptive behavior is that the children in the SOEP sample seem to be somewhat too old for the tested abilities; $90 \%$ of children in our sample achieved the highest possible score in two out of four sub-dimensions of the test (cf. Schmiade et al. 2008).

${ }^{11}$ See Berger and Spieß (2011) for definitions and the aggregation of the scores.

${ }^{12}$ Schmiade et al. (2008) summarize the use of the Vineland Scale in the SOEP and the corresponding score which reflects the overall degree of the child's development.
} 
also provides the opportunity to perform a falsification test on the estimating equation. Because the Vineland is collected when the child is three years of age and we observe health shocks until the child is six years of age, we are able to estimate the effects of past and future parental health shocks. If parental health shocks alter outcomes and the model is correctly specified then we should estimate that future parental health shocks do not alter the outcomes of children. We standardized each of the measures to have a mean of zero and a standard deviation of one (z-scores) such that higher z-scores indicate more favorable outcomes.

Table 1 provides the mean values of child skill measures for the entire sample (column 1) and means conditional on the level of the parents' self-rated health satisfaction when the child is about six years old. Approximately 20 percent of parents are in "bad" health when their child is six years old, corresponding to the lowest health quintile of the health satisfaction distribution. Table 1 shows that children of healthy parents have better measures of socio-emotional skills. The averages of the overall difficulty score are about 0.4 and 0.01 standard deviations lower (worse) for children whose mothers and fathers are in bad health, respectively. The individual scales of the SDQ suggest that having a less healthy father or mother is related to less favorable outcomes: A lower emotional symptom score; conduct problem score; hyperactivity score; peer-relation score; as well as a the pro-social behavior score is lower for children whose mother is in bad health compared to children with a healthy mother. In contrast, children of fathers in bad health have less hyperactivity symptoms and score slightly higher on the adaptive behavior score than those with fathers in good health, although the differences are not statistically significant.

Table 1 further shows the mean Vineland scores informing on children's adaptive behavior at age three. There are no significant differences in the adaptive behavior score at age three conditional on parental health at age six. Table 1 suggests that parental health is related to children's non-cognitive outcomes, more strongly so for maternal than paternal health. However, the descriptive statistics in Table 1 do not condition on any other observed differences that may be related to both parental health and children's skills. Parental human capital and child human capital are interrelated for instance via the genetic endowment and similar experiences made in life such as environmental and living conditions. In other words, if we observe less favorable non-cognitive outcomes for children whose parents suffer from bad health, this may be a correlated effect of other, related variables (for instance household income) instead of health. In Section 3, we therefore focus on health shocks rather than the level of health and make use of multivariate analyses in order to estimate the effects of parental health limitations on child outcomes. 


\section{Empirical Approach}

In order to estimate the effects of parental health, we examine parental health shocks instead of health levels. By using significant one period changes in the health variables rather than movement below a "poor" health threshold, we aim at identifying exogenous shocks rather than poor health ratings or health deterioration which is endogenous to child outcomes. More specifically, the identification assumption is that, conditional on the level of health and other covariates, significant changes in health are exogenous. We estimate the following reduced form specification:

$$
Y_{i}=\alpha+\beta_{1} M H S_{i}^{0-3}+\beta_{2} M H S_{i}^{3-6}+\gamma_{1} P H S_{i}^{0-3}+\gamma_{2} P H S_{i}^{3-6}+X_{i} \delta+\varepsilon_{i}
$$

Children's non-cognitive outcome $Y_{i}$ is based on the SDQ test scores at age 6 or the Vineland adaptive behavior scale, VAB, at about age three. "MHS" (= maternal health shock) and "PHS" (= paternal health shock) records whether the specific parent was subject of a health shock before or after the child was three years of age. In addition, all our regressions control for available variables that are considered to be related to the children's initial endowments in the vector $X_{i}$ including parental education, immigration background and household income (all variables observed at the time of birth), parental initial health satisfaction and initial nights to be hospitalized (both observed one year before birth), children's gender, birth order, week of pregnancy at birth date, birth weight, and a second order polynomial of the age of the mother at birth (measured in months). ${ }^{13}$ We additionally include the age of the child, measured in months and its square at the time of observation. Table A1 in the appendix lists all control variables along with their means and standard deviations.

The frequencies of health shocks according to each of the four definitions from above are shown in the tables presenting results based upon these definitions-Tables 2 and 3. Generally, the frequency of maternal health shocks is higher than the frequency of paternal health shocks. ${ }^{14}$ Since there are hardly any paternal health shocks according to the definition in specification 4, we have to treat fathers' health shocks in this specification with caution. All specifications include both maternal and paternal health shocks.

\footnotetext{
${ }^{13}$ For observations missing information on parental education or migration status, we set these values equal to zero and include and indicator variable representing that these values are missing.

${ }^{14}$ Part of this difference is due to the fact that there are single-mothered households in our sample. According to Table 1, about 21 percent of the children are growing up without a father.
} 


\section{Results}

Table 2 shows the estimated impact of parental health shocks on children's socio-emotional development. For each outcome, Panels A to F, we estimate four specifications that vary with the definition of parental health shock, specifications (1) through (4). Specification (1) uses the broadest definition of a shock, either a two standard deviation reduction in health satisfaction (four points) or a one standard deviation increase in the number of nights to be hospitalized over the previous year (4 nights for fathers and 6 nights for mothers). Specifications (2) and (3) use shocks defined solely based on changes in health satisfaction and nights to be hospitalized, respectively. Specification (4) uses the strictest definition of a health shock, requiring both a decrease in reported health satisfaction and an increase in hospitalizations.

Panel A provides the estimated impact of the different health shock specifications on the overall difficulty score (SEB). Maternal shocks at ages 3-6 are estimated to significantly and negatively affect the child's overall difficulty score. The findings are robust for all specifications of a health shock. Estimates range from 0.36 to 0.95 standard deviation reductions, with the largest effect estimated for the strictest definition of a shock. Panels B to E examine effects of parental health shocks on the sub-components of the SEB score.

Panel B shows that maternal shocks that occurring from ages 3 to 6 decrease the emotional symptoms score by roughly one half of a standard deviation. Panel $\mathrm{C}$ shows for specification 1 that experiencing any kind of observed maternal health shock in the last 3 years of the childhood observation period decreases the hyperactivity problem score by 0.2 standard deviations or more. However, the estimates are not precisely estimated and lose statistical significance in the stricter health shock specifications.

Panel D provides the estimates of the health shock specifications on the conduct problems of a child. Again, maternal health shocks at ages 3-6 negatively affect the outcome. The size of the estimated effect is similar to the previous outcomes, roughly 0.2 to 0.25 standard deviations, with larger negative impacts (-0.85 s.d.) for the strictest specification, a maternal shock in health satisfaction and hospitalization.

Panel E indicates that maternal health shocks, at ages 3-6, are not strongly related to the child exhibiting peer relationship problems. While the coefficient estimates are negative, we do not have the necessary power to identify these smaller effects. While maternal shocks at ages 3-6 are found to worsen the overall difficulty score, and components of the score, Panel F shows that parental health shocks are not estimated to worsen the indicator of the child's pro-social behavior. 
In a next step, we conduct robustness checks in order to challenge our identification assumption. If it is true that considering parental health shocks allows identifying causal effects of parental health, we would expect that parental health shocks affect future child outcomes while they are not correlated to past child outcomes given the other covariates in the model. If parental health shocks also affect past outcomes, this would question the validity of our approach. We are able to conduct robustness checks along this line based on the Vineland score on adaptive behavior, which we observe for the three-year-olds. In a first robustness check, we regress the Vineland score on parental health shocks that occur prior to taking the test and shocks that occur after the child has taken the test. If time constant unobserved variables that are correlated with the occurrence of a health shock are driving the results the timing of the shock should not matter in the falsification test. ${ }^{15}$ Additionally, we control for the same set of control variables that are included in our main regressions. In a second check, we regress adaptive behavior solely on future parental health shocks and the control variables ("placebo regressions").

The results for the Vineland Scale on adaptive behavior are shown in Table 3. Because this is an outcome we observe when the children are about three years old, we are also able to estimate how future health shocks (occurring when children are aged three to six) are correlated with this outcome. Table 3 shows that the past maternal health shocks negatively impact standardized child adaptive behavior at age three. Specification 1 suggests that the effect of past maternal health shocks increases the VAB by about one fifth of a standard deviation. The effect of other past health shock specifications $(2-4)$ is not significant. However, the estimated coefficients for the maternal health shocks are robust if we compare the point estimates of the different specifications.

Evidence on the future health shocks is provided in the bottom panels of Table 3. The negative impact of past maternal health shocks on adaptive behavior is robust when future health shocks are included. The results imply consistently that future health shocks are not significantly related to the children's adaptive behavior at age 3. This is true if both future health shocks and past health shocks are included in the regressions but also if only future health shocks are considered (placebo regressions). None of the health shock coefficients in the placebo regressions are statistically significant at the ten percent level of significance, and the point estimates for maternal health shocks are positive rather than negative. The large but

\footnotetext{
${ }^{15}$ If unobserved events systematically occur at a time near the reported health shocks then we may still falsely attribute the effect to a health shock. However, we examine whether controlling for single-parents, annual net income, divorce or parental split-off, maternal and paternal job-losses, as indicators of alternative events, and find that the results are not different.
} 
still insignificant effect of the severest future paternal health shock should be treated with caution, because of the low number of observations, whose father experiencing such a strong health shock.

As robustness checks, Table A2 shows the regression results estimating the effect of maternal health shocks when the child is aged 3-6 years and includes additional "shocks" that may have occurred during the same time period. The additional shocks include indicators for maternal or paternal job-losses and parental split-off or divorce. Furthermore, we perform additional specifications with controls for the household net-income in each year of the observation period and find that they do not qualitatively change the estimated coefficients of parental health shocks. ${ }^{16}$

\section{Conclusions}

In line with previous studies our paper provides evidence on the importance of parental investments into their children's skill formation process early in life. We interpret our findings as evidence that an involuntary change in parental investment due to a health shock has significantly worsened outcome measures of children's non-cognitive skills. Specifically, maternal health shocks when the child is aged 3-6 years are found to negatively affect the child's emotional symptoms, conduct problems and hyperactivity. Reductions in these outcomes are of a magnitude of 0.2 to 0.5 standard deviations for the more commonly experienced definition of health shock and between 0.62 and 0.95 standard deviations for our strictest health shock definition. No consistent effects are found as the result of a paternal health shock or when the health shock occurs when the children are 0 to 3 years of age. The effects are less pronounced for paternal health shocks. The late maternal health shocks decreases the observed non-cognitive skills up to a half standard deviation. Our results are robust with respect to potential other shock sources.

The specific importance of maternal health for children's favorable development is likely to be caused by the fact that the mother is the traditional child caregiver in the German family. If maternal health causes a decrease in the potential time or quality of time and resources a mother can invest into her child's development, this will have significant effects in the absence of an alternative child caregiver. However, father's hospitalization shocks seem

\footnotetext{
${ }^{16}$ Further regressions with additional dummies for positive shocks in health satisfaction, defined with the same restrictions as the negative ones, do not change the estimates for the negative health shock definitions. However, regressions with only positive shocks in health satisfaction cover about $50 \%$ of the significant estimates from the negative shock regressions. These can be explained with a high overlap of parents experience first a negative and then a positive health shock, due to recovery.
} 
to interfere with children's problem behavior too. In light of this interpretation, our results suggest that there is scope to introduce measures that support mothers affected by illnesses in order to reduce the observed negative effects on child development. To this end, additional support by external caregivers or more flexible working times for sick mothers' partners in order to care for the family may be effective measures. The evaluation of such policies is left for future research.

\section{References}

Adda, J., J. Banks and H.M. von Gaudecker (2009): The Impact of Income Shocks on Health: Evidence from Cohort Data, Journal of the European Economic Association, 7(6), 1361-1399.

Adda, J., A. Björklund and H. Holmlund (2011): The Role of Mothers and Fathers in Providing Skills: Evidence from Parental Deaths, IZA Discussion Paper, 5425.

Albers, A.B. and S.M. Petterson(2001): Effects of Poverty and Maternal Depression on Early Child Development, Child Development, 72, 1794-1813. 
Andrews, R.J. and T.D.Logan (2010): Family Health, Children's own Health and Test Score Gaps, American Economic Review Paper and Proceedings, 100, 195-199

Belfield, C.R. and I.R. Kelly (2012): The Benefits of Breast Feeding across the Early Years of Childhood, Journal of Human Capital, 6(3), 251 - 277.

Berger, E.M., F. Peter and C.K. Spieß (2010): Wie hängen familiäre Veränderungen und das mütterliche Wohlbefinden mit der frühkindlichen Entwicklung zusammen?, Quarterly Journal of Economic Research, 79, 27-44.

Berger, E.M. and C.K. Spieß (2011): Maternal Life Satisfaction and Child Outcomes: Are They Related?, Journal of Economic Psychology, 1, 142-158.

Blomeyer, D., K. Coneus, M. Laucht, and F. Pfeiffer (2009): Initial Risk Matrix, Home Resources, Ability Development and Children's Achievement, Journal of the European Economic Association, 7(2-3), 638-648.

Carneiro, P. and J.J. Heckman (2003): "Human Capital Policy." in J.J. Heckman and A.B. Krueger (eds.): Inequality in America: What Role for Human Capital Policies? Cambridge, MA: MIT Press.

Caspi, A., J. Kim-Cohen, T.E. Moffit, S. Pawlby and A. Taylor (2005): Maternal Depression and Children's Antisocial Behavior, Archives of General Psychiatry, 62, 173-181.

Castilla, E.E., A.M. McCarthy, J.C. Murray, K. Prater and G.L. Wehby (2011): The Impact of Maternal Smoking during Pregnancy on Early Child Neurodevelopment, Journal of Human Capital, 5(2), 207-254.

Crouse, J., M. Phillips and J. Ralph (1998): Does the black-white test score gap widen after children enter school? In C. Jencks and M. Phillips (eds.): The black-white test score gap). Washington, DC: Brookings.

Cunha, F., J.J. Heckman, L. Lochner and D.V. Masterov (2006): Interpreting the Evidence on Life Cycle Skill Formation, in A. Hanushek and F. Welch (eds.): Handbook of the Economics of Education, North-Holland.

Currie, J. and B.C. Madrian (1999): Health, Health Insurance and the Labor Market, in O. Ashenfelter and R. Layard (eds.): Handbook of Labor Economics, North-Holland.

Farahati, F., D.E. Marcotte and V. Wilcox-Gok (2003): The Effects of Parents' Psychiatric Disorders on Children's High School Dropout, Economics of Education Review, 22, 167-178.

Frank, R.G. and E. Meara (2009): The Effect of Maternal Depression and Substance Abuse on Child Human Capital Development, NBER Working Paper Series, 15314. 
Fryer, R.G. (Jr.) and S.D. Levitt (2004): Understanding the Black-White Test Score Gap in the First Two Years of School, Review of Economics and Statistics, 86(2), 447-464.

Goodman, R. (1997): The Strengths and Difficulties Questionnaire: A Research Note, Journal of Child Psychology and Psychiatry, 38, 581-586.

Hagan, R., A.M. Jones and N. Rice (2009): Health and Retirement in Europe, International Journal of Environmental Research and Public Health, 6(10), 2676-2695.

Heckman, J.J. (2000): Policies to foster human capital, Research in Economics, 54(1), 3-56.

Morefield, B. (2010): Parental Health Events and Children's Skill Development, Working Papers 10-11, University of North Carolina at Greensboro, Department of Economics.

Rees, D.I. and J. J. Sabia (2009): The Effect of Breastfeeding on Educational Attainment: Evidence from Sibling Data, Journal of Human Capital, 3(1), 43-72.

Ribar, D. (2004): What Do Social Scientists Know About the Benefits of Marriage? A Review of Quantitative Methodologies, IZA Discussion Paper, 998.

Riphahn, R.T. (1999): "Income and Employment Effects of Health Shocks A Test for the German Welfare State.” Journal of Population Economics, 12(3), 363-389.

Ruhm, C.J. (2004): Parental Employment and Child Cognitive Development, Journal of Human Resources, 39(1), 155-192.

Schmiade, N., C.K. Spieß and W. Tietze (2008): Zur Erhebung des adaptiven Verhaltens von zwei- und dreijährigen Kindern im Sozio-oekonomischen Panel (SOEP), SOEPpapers on Multidisciplinary Panel Data Research, 116.

Schneider, H. (2008): Natürliche Geburt oder Wunsch -Sectio, Der Gynäkologe, 41, 36-41.

Smith, J.P. (2004): Unraveling the SES-Health Connection, Population and Development Review, 30, Supplement: Aging, Health, and Public Policy, 108-132.

Sun, A. and Y. Yao (2010): Health Shocks and Children's School Attainments in Rural China, Economics of Education Review, 29, 375-382.

Todd, P. E., and K. I. Wolpin (2007): “The Production of Cognitive Achievement in Children: Home, School, and Racial Test Score Gaps.” Journal of Human Capital, 1(1), 91-136.

Wu, S. (2003): “The Effects of Health Events on the Economic Status of Married Couples." Journal of Human Resources, 38(1), 219-230. 
Tables

Table 1: Parental health satisfaction and children's socio-emotional behavior (Age 6), Vineland Adaptive Behavior (Age 3)

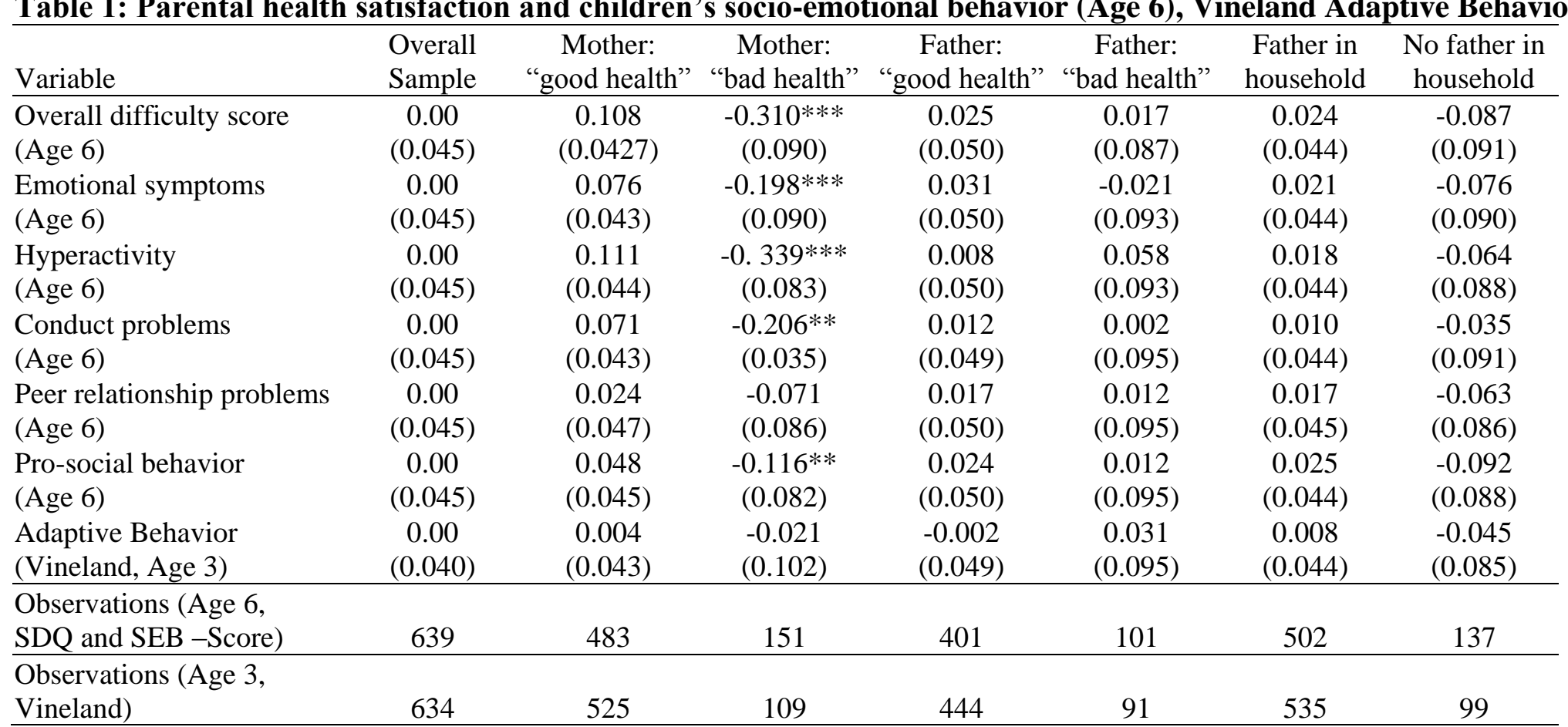

Note: Means (and standard errors) of the respective variables. * Marks the significant difference between a parent in good and a parent in bad health at the ten percent level, ** at the five percent and *** at the one percent level. We consider parents to be of "good" health if they rate their own health as good at the (i.e. between 6 to 10 on the eleven point scale) and to be of "bad" health if they report intermediate or bad health (values 0 to 5 on the eleven point scale). We do not observe health satisfaction for five mothers. However, information on these five mothers is still used in the regression analysis because we observe their health history after childbirth as well as the required child outcomes.

Source: Mother and child data of the German Socio-Economic Panel Study (SOEP), v28. Own calculations. 
Table 2: Impact of health shocks on children's socio-emotional development (Age 6)

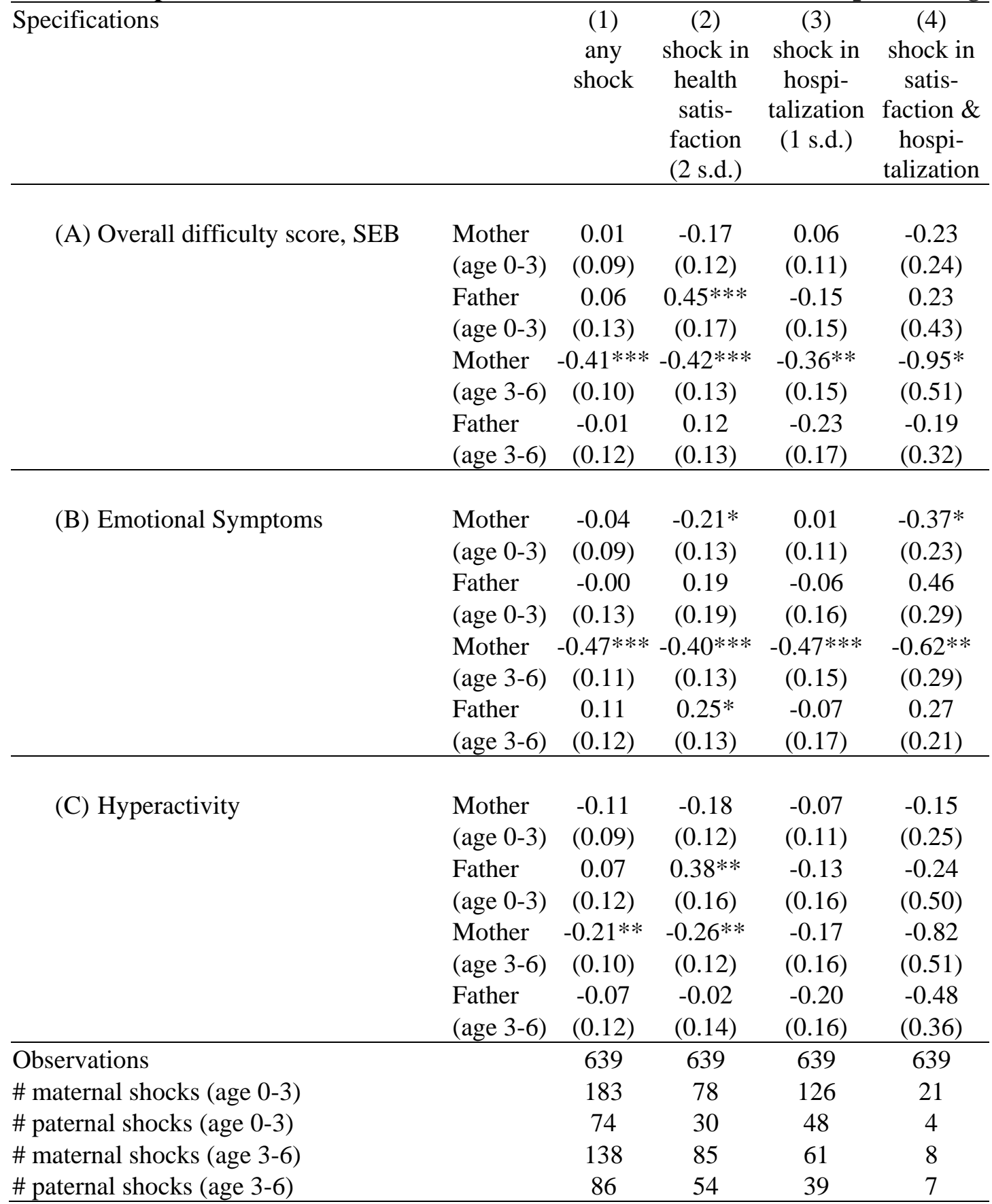

(to be continued on next page) 
Table 2: (continued)

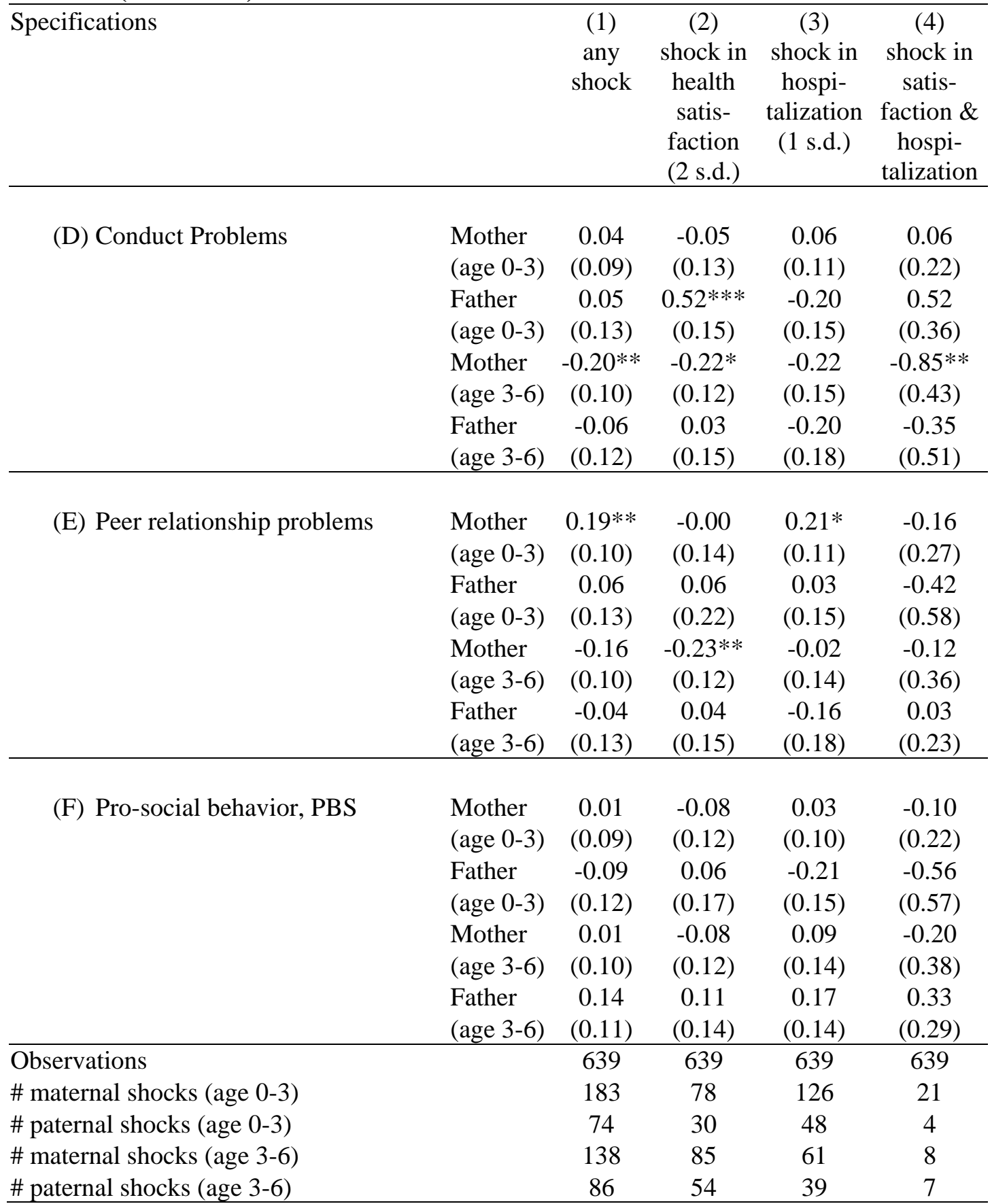

Note: Coefficients (robust standard errors) from regressions using the SOEP v28. All regressions control for parental initial health satisfaction and hospitalization, education and immigrant background, household income before birth, children's gender, birth order, week of pregnancy at birth date, birth weight, a second order polynomial of the age of the mother at childbirth and a second order polynomial of the children's age at time of observation. All outcome variables are standardized test scores (z-score). * Significant at the ten percent level of significance. $* *$ Significant at the five percent level. $* * *$ Significant at the one percent level. s.d. $=$ standard deviation. 
Table 3: Impact of health shocks on adaptive behavior and robustness checks (Age 3)

\begin{tabular}{|c|c|c|c|c|c|}
\hline \multicolumn{2}{|l|}{ Specifications } & $\begin{array}{c}(1) \\
\text { any } \\
\text { shock }\end{array}$ & $\begin{array}{c}(2) \\
\text { shock in } \\
\text { health } \\
\text { satis- } \\
\text { faction } \\
(2 \text { s.d. })\end{array}$ & $\begin{array}{l}(3) \\
\text { shock in } \\
\text { hospi- } \\
\text { talization } \\
\text { (1 s.d.) }\end{array}$ & $\begin{array}{c}(4) \\
\text { shock in } \\
\text { satis- } \\
\text { faction \& } \\
\text { hospi- } \\
\text { talization }\end{array}$ \\
\hline \multicolumn{6}{|c|}{ Effects of past parental health shocks at age 3} \\
\hline (A) Past health shocks & $\begin{array}{l}\text { Mother } \\
\text { (age 0-3) } \\
\text { Father } \\
\text { (age 0-3) }\end{array}$ & $\begin{array}{c}-0.18^{*} \\
(0.09) \\
0.13 \\
(0.10)\end{array}$ & $\begin{array}{c}-0.16 \\
(0.13) \\
-0.03 \\
(0.14)\end{array}$ & $\begin{array}{c}-0.16 \\
(0.10) \\
0.21 \\
(0.13)\end{array}$ & $\begin{array}{l}-0.21 \\
(0.28) \\
-0.21 \\
(0.52)\end{array}$ \\
\hline
\end{tabular}

\begin{tabular}{|c|c|c|c|c|c|}
\hline \multicolumn{6}{|c|}{ Robustness check 1: Effects of past and future parental health shocks at age 3} \\
\hline \multirow[t]{4}{*}{ (B) Past health shocks } & Mother & $-0.18 * *$ & -0.16 & -0.14 & -0.22 \\
\hline & (age $0-3)$ & $(0.09)$ & $(0.13)$ & $(0.10)$ & $(0.28)$ \\
\hline & Father & 0.13 & -0.04 & $0.23 *$ & -0.20 \\
\hline & (age 0-3) & $(0.10)$ & $(0.14)$ & $(0.13)$ & $(0.51)$ \\
\hline \multirow[t]{4}{*}{ Future health shocks } & Mother & 0.05 & 0.14 & -0.05 & 0.27 \\
\hline & (age 3-6) & $(0.10)$ & $(0.11)$ & $(0.15)$ & $(0.33)$ \\
\hline & Father & -0.01 & 0.11 & -0.14 & 0.09 \\
\hline & (age 3-6) & $(0.10)$ & $(0.10)$ & $(0.16)$ & $(0.26)$ \\
\hline \multicolumn{6}{|c|}{ Robustness check 2: Effects of future health shocks at age 3 (Placebo regressions) } \\
\hline \multirow[t]{4}{*}{ (C) Future health shocks } & Mother & 0.04 & 0.14 & -0.06 & 0.25 \\
\hline & (age 3-6) & $(0.10)$ & $(0.10)$ & $(0.15)$ & $(0.37)$ \\
\hline & Father & -0.01 & 0.12 & -0.14 & 0.09 \\
\hline & (age 3-6) & $(0.10)$ & $(0.10)$ & $(0.16)$ & $(0.26)$ \\
\hline \multicolumn{2}{|l|}{ Observations } & 634 & 634 & 634 & 634 \\
\hline \multicolumn{2}{|l|}{ \# maternal shocks (age 0-3) } & 180 & 75 & 128 & 23 \\
\hline \multicolumn{2}{|l|}{ \# paternal shocks (age 0-3) } & 70 & 29 & 44 & 3 \\
\hline \multicolumn{2}{|l|}{ \# maternal shocks (age 3-6) } & 143 & 87 & 63 & 7 \\
\hline \multicolumn{2}{|l|}{ \# paternal shocks (age 3-6) } & 86 & 53 & 39 & 6 \\
\hline
\end{tabular}

Note: Coefficients (robust standard errors) from regressions using the SOEP v28. All regressions control for parental initial health satisfaction and hospitalization, education and immigrant background, household income before birth, children's gender, birth order, week of pregnancy at birth date, birth weight, a second order polynomial of the age of the mother at childbirth and a second order polynomial of the children's age at time of observation. All outcome variables are standardized test scores (z-score). * Significant at the ten percent level of significance. $* *$ Significant at the five percent level. $* * *$ Significant at the one percent level. s.d. $=$ standard deviation . 


\section{Appendix}

Table A1: Means (standard deviations) of control variables included in the main regression analysis

\begin{tabular}{|c|c|c|}
\hline & $\begin{array}{c}\text { Socio-emotional } \\
\text { development } \\
\text { sample } \\
\end{array}$ & $\begin{array}{c}\text { Adaptive } \\
\text { behavior } \\
\text { sample }\end{array}$ \\
\hline $\begin{array}{l}\text { Tertiary education of parents indicator } \\
\text { (observed at birth) }\end{array}$ & $\begin{array}{c}0.59 \\
(0.49)\end{array}$ & $\begin{array}{c}0.59 \\
(0.49)\end{array}$ \\
\hline Missing indicator for parental education & $\begin{array}{c}0.08 \\
(0.27)\end{array}$ & $\begin{array}{c}0.09 \\
(0.28)\end{array}$ \\
\hline $\begin{array}{l}\text { Parental migration background indicator } \\
\text { (observed at birth) }\end{array}$ & $\begin{array}{c}0.16 \\
(0.35)\end{array}$ & $\begin{array}{c}0.16 \\
(0.37)\end{array}$ \\
\hline $\begin{array}{l}\text { Missing indicator for parental migration } \\
\text { background }\end{array}$ & $\begin{array}{c}0.08 \\
(0.28)\end{array}$ & $\begin{array}{c}0.09 \\
(0.29)\end{array}$ \\
\hline $\begin{array}{l}\text { Maternal initial health satisfaction } \\
\text { (observed before birth) }\end{array}$ & $\begin{array}{c}7.58 \\
(1.89)\end{array}$ & $\begin{array}{c}7.56 \\
(1.90)\end{array}$ \\
\hline $\begin{array}{l}\text { Paternal initial health satisfaction } \\
\text { (observed before birth) }\end{array}$ & $\begin{array}{c}7.52 \\
(1.90)\end{array}$ & $\begin{array}{c}7.51 \\
(1.88)\end{array}$ \\
\hline $\begin{array}{l}\text { Maternal initial hospitalization nights } \\
\text { (observed before birth) }\end{array}$ & $\begin{array}{c}1.15 \\
(4.38)\end{array}$ & $\begin{array}{c}1.21 \\
(4.48)\end{array}$ \\
\hline $\begin{array}{l}\text { Paternal initial hospitalization nights } \\
\text { (observed before birth) }\end{array}$ & $\begin{array}{c}0.80 \\
(4.82)\end{array}$ & $\begin{array}{c}0.67 \\
(4.00)\end{array}$ \\
\hline $\begin{array}{l}\text { Monthly household income } \\
\text { (CPI adjusted, observed before birth) }\end{array}$ & $\begin{array}{c}2527.68 \\
(1261.70)\end{array}$ & $\begin{array}{c}2528.36 \\
(1267.80)\end{array}$ \\
\hline $\begin{array}{l}\text { Missing indicator for household income } \\
\text { (not observed before birth) }\end{array}$ & $\begin{array}{c}0.17 \\
(0.38)\end{array}$ & $\begin{array}{c}0.17 \\
(0.38)\end{array}$ \\
\hline Gender: male indicator & $\begin{array}{c}0.48 \\
(0.50)\end{array}$ & $\begin{array}{c}0.47 \\
(0.50)\end{array}$ \\
\hline $\begin{array}{l}\text { Age of child } \\
\text { (in months, last measurement point) }\end{array}$ & $\begin{array}{l}69.06 \\
(3.80)\end{array}$ & $\begin{array}{l}69.11 \\
(3.82)\end{array}$ \\
\hline Age of child squared & $\begin{array}{l}4783.81 \\
(525.36)\end{array}$ & $\begin{array}{l}4791.24 \\
(529.03)\end{array}$ \\
\hline Birth order: first born indicator & $\begin{array}{l}0.45 \\
(0.50)\end{array}$ & $\begin{array}{c}0.45 \\
(0.50)\end{array}$ \\
\hline Age of mother at birth & $\begin{array}{l}30.78 \\
(5.27)\end{array}$ & $\begin{array}{l}30.73 \\
(5.30)\end{array}$ \\
\hline Age of mother at birth squared & $\begin{array}{c}975.29 \\
(325.62)\end{array}$ & $\begin{array}{c}972.52 \\
(326.92)\end{array}$ \\
\hline Week of pregnancy at childbirth & $\begin{array}{l}39.12 \\
(2.32)\end{array}$ & $\begin{array}{l}39.09 \\
(2.37)\end{array}$ \\
\hline Birth weight of child (in g) & $\begin{array}{l}3339.88 \\
(573.96)\end{array}$ & $\begin{array}{l}3333.36 \\
(583.29)\end{array}$ \\
\hline \# Observations & 639 & 634 \\
\hline
\end{tabular}

Source: Mother and child data of the German Socio-Economic Panel Study (SOEP), v28. Own calculations. 
Table A2: Robustness checks

\begin{tabular}{|c|c|c|c|c|c|}
\hline Specifications & & $\begin{array}{c}(1) \\
\text { any } \\
\text { shock }\end{array}$ & $\begin{array}{c}(2) \\
\text { shock in } \\
\text { health } \\
\text { satis- } \\
\text { faction } \\
\text { (2 s.d.) }\end{array}$ & $\begin{array}{l}(3) \\
\text { shock in } \\
\text { hospi- } \\
\text { talization } \\
\text { (1 s.d.) }\end{array}$ & $\begin{array}{c}(4) \\
\text { shock in } \\
\text { satis- } \\
\text { faction \& } \\
\text { hospi- } \\
\text { talization }\end{array}$ \\
\hline (A) Overall difficulty score, SEB & $\begin{array}{l}\text { Mother } \\
\text { (age 3-6) }\end{array}$ & $\begin{array}{c}-0.41 * * * \\
(0.10)\end{array}$ & $\begin{array}{c}-0.42 * * * \\
(0.13)\end{array}$ & $\begin{array}{c}-0.36^{* *} \\
(0.15)\end{array}$ & $\begin{array}{l}-0.95 * \\
(0.51)\end{array}$ \\
\hline (A) + additional controls & $\begin{array}{l}\text { Mother } \\
\text { (age 3-6) }\end{array}$ & $\begin{array}{c}-0.40 * * * \\
(0.11)\end{array}$ & $\begin{array}{c}-0.40 * * * \\
(0.13)\end{array}$ & $\begin{array}{c}-0.37 * * \\
(0.15) \\
\end{array}$ & $\begin{array}{l}-0.95^{*} \\
(0.51)\end{array}$ \\
\hline (B) Emotional Symptoms & $\begin{array}{l}\text { Mother } \\
\text { (age 3-6) }\end{array}$ & $\begin{array}{c}-0.47 * * * * \\
(0.11)\end{array}$ & $\begin{array}{c}-0.40 * * * \\
(0.13)\end{array}$ & $\begin{array}{c}-0.47 * * * \\
(0.15)\end{array}$ & $\begin{array}{c}-0.62 * * \\
(0.29)\end{array}$ \\
\hline (B) + additional controls & $\begin{array}{l}\text { Mother } \\
\text { (age 3-6) }\end{array}$ & $\begin{array}{c}-0.45 * * * \\
(0.11)\end{array}$ & $\begin{array}{c}-0.38 * * * \\
(0.13) \\
\end{array}$ & $\begin{array}{c}-0.47 * * * \\
(0.16) \\
\end{array}$ & $\begin{array}{c}-0.65^{* *} \\
(0.31) \\
\end{array}$ \\
\hline (C) Hyperactivity & $\begin{array}{l}\text { Mother } \\
\text { (age 3-6) }\end{array}$ & $\begin{array}{c}-0.21 * * \\
(0.10)\end{array}$ & $\begin{array}{c}-0.26^{* *} \\
(0.12)\end{array}$ & $\begin{array}{l}-0.17 \\
(0.16)\end{array}$ & $\begin{array}{l}-0.82 \\
(0.51)\end{array}$ \\
\hline (C) + additional controls & $\begin{array}{l}\text { Mother } \\
\text { (age 3-6) }\end{array}$ & $\begin{array}{c}-0.22 * * \\
(0.10) \\
\end{array}$ & $\begin{array}{l}-0.23 * \\
(0.12) \\
\end{array}$ & $\begin{array}{l}-0.19 \\
(0.15) \\
\end{array}$ & $\begin{array}{l}-0.83^{*} \\
(0.50) \\
\end{array}$ \\
\hline (D) Conduct Problems & $\begin{array}{l}\text { Mother } \\
\text { (age 3-6) }\end{array}$ & $\begin{array}{c}-0.20 * * \\
(0.10)\end{array}$ & $\begin{array}{l}-0.22 * \\
(0.12)\end{array}$ & $\begin{array}{l}-0.22 \\
(0.15)\end{array}$ & $\begin{array}{c}-0.85^{* *} \\
(0.43)\end{array}$ \\
\hline (D) + additional controls & $\begin{array}{l}\text { Mother } \\
\text { (age 3-6) }\end{array}$ & $\begin{array}{c}-0.20^{*} \\
(0.10) \\
\end{array}$ & $\begin{array}{l}-0.21 * \\
(0.12) \\
\end{array}$ & $\begin{array}{l}-0.22 \\
(0.15) \\
\end{array}$ & $\begin{array}{c}-0.82^{* *} \\
(0.41) \\
\end{array}$ \\
\hline Observations & & 639 & 639 & 639 & 639 \\
\hline \# maternal shocks (age 0-3) & & 183 & 78 & 126 & 21 \\
\hline \# paternal shocks (age 0-3) & & 74 & 30 & 48 & 4 \\
\hline \# maternal shocks (age 3-6) & & 138 & 85 & 61 & 8 \\
\hline \# paternal shocks (age 3-6) & & 86 & 54 & 39 & 7 \\
\hline
\end{tabular}

Note: Coefficients (robust standard errors) from regressions using the SOEP v28. All regressions control for parental initial health satisfaction and hospitalization, education and immigrant background, household income before birth, children's gender, birth order, week of pregnancy at birth date, birth weight, a second order polynomial of the age of the mother at childbirth and a second order polynomial of the children's age at time of observation. The specification '+ additional controls' includes further the initial parental health status, maternal or paternal job-losses, parental split-off or divorce as potential other shock sources. All outcome variables are standardized test scores (z-score). * Significant at the ten percent level of significance. $* *$ Significant at the five percent level. *** Significant at the one percent level. s.d. $=$ standard deviation. 
Table A3: Items of the Strengths and Difficulties Questionnaire (SDQ)

According to Goodman (1997):

Hyperactivity Scale: "Restless, overactive, cannot stay still for long"; "Constantly fidgeting or squirming"; "Easily distracted, concentration wanders"; "Thinks things out before acting" and "Sees tasks through to the end, good attention span".

Emotional Symptoms Scale: "Often complains of headaches, stomach-ache or sickness"; "Many worries, often seems worried"; "Often unhappy, down-hearted or tearful"; "Nervous or clingy in new situations, easily loses confidence"; and "Many fears, easily scared".

Conduct Problems Scale: "Often has temper tantrums or hot tempers"; "Generally obedient, usually does what adults request"; "Often fights with other children or bullies them"; "Often lies or cheats"; and "Steals from home, school or elsewhere".

Peer Problems Scale: "Rather solitary, tends to play alone"; "Has at least one good friend"; "Generally liked by other children"; "Picked on or bullied by other children"; and "Gets on better with adults than with other children".

Pro-social Scale: "Considerate of other people's feelings"; "Shares readily with other children (treats, toys, pencils, etc.)"; "Helpful if someone is hurt, upset or feeling ill"; "Kind to younger children"; and "Often volunteers to help others (parents, teachers, other children)".

Table A4: Items of the Vineland adaptive behavior scale (VAB), SOEP-Version

Talking: "Understands brief instructions such as 'go get your shoes"”; "Forms sentences with at least two words"; "Speaks in full sentences (with four or more words)"; "Listens attentively to a story for five minutes or longer"; "Passes on simple messages such as "dinner is ready",

Everyday skills: "Uses a spoon to eat, without assistance and without dripping"; "Blows his/her nose without assistance"; "Uses the toilet to do "number two",; "Puts on pants and underpants the right way around"; "Brushes his/her teeth without assistance"

Movement: "Walks forwards down the stairs"; "Opens doors with the door handle"; "Climbs up playground climbing equipment and other high playground structures"; "Cuts paper with scissors"; "Paints/draws recognizable shapes on paper"

Social relationships: "Calls familiar people by name; for example, says 'mommy' and 'daddy' or uses the father's first name"; "Participates in games with other children"; "Gets involved in role-playing games ("playing pretend')"; "Shows a special liking for particular playmates or friends"; "Calls his/her own feelings by name, e.g. 'sad', 'happy', 'scared'” 